\title{
Impact of Changing Swidden-Based Farming to Rubber-Based Farming on Food Security in Luang Namtha Province, Lao PDR
}

\author{
Anan Polthanee, Arunee Promkhambut, Satit Aditto and Avakat Phasouysaingam * (D) \\ Faculty of Agriculture, Khon Kaen University, Khon Kaen 40002, Thailand; panan@kku.ac.th (A.P.); \\ arunee@kku.ac.th (A.P.); asatit@kku.ac.th (S.A.) \\ * Correspondence: a.phasouysaingam@nuol.edu.la; Tel.: +856-20-2945-1315
}

Citation: Polthanee, A.;

Promkhambut, A.; Aditto, S.;

Phasouysaingam, A. Impact of

Changing Swidden-Based Farming to Rubber-Based Farming on Food Security in Luang Namtha Province, Lao PDR. Sustainability 2021, 13, 7617. https://doi.org/10.3390/su13147617

Academic Editor: Hossein Azadi

Received: 10 June 2021

Accepted: 4 July 2021

Published: 7 July 2021

Publisher's Note: MDPI stays neutral with regard to jurisdictional claims in published maps and institutional affiliations.

\begin{abstract}
Although swidden-based farming has traditionally been practiced by the people in Lao PDR, this system is considered to result in significant environmental degradation. Thus, rubber-based farming was introduced as an alternative to food crops grown under swidden farming, thereby affecting household food security. Thus, this study aimed to compare the impacts of traditional swidden-based farming (SBF), rubber-based farming (RBF), and swidden-rubber-based farming on food security in Luang Namtha province, Laos. Two villages were selected for a case study. A total sample of 195 households was selected using the stratified random sampling method. A face-toface household $(\mathrm{HH})$ questionnaire was used for interviews. The results showed that households practicing RBF alone showed the lowest level of food security and highest vulnerability in terms of food security. No households in this group reached the food security level. The SRBF group exhibited a greater level of food security than that of either SBF or RBF alone. Two dimensions of food security — food availability and food access-were used to investigate the household food security level associated with the three farming types in this paper.
\end{abstract}

Keywords: swidden-based farming; rubber-based farming; swidden and rubber-based farming; food security

\section{Introduction}

Food insecurity is a major issue in many Asian countries because of the region's large rural population, low-productivity farming, weak markets, and high climatic risk [1]. Since the 18th century, Thomas Malthus predicated that the population would increase according to a geometric ratio, whereas agricultural production would increase via an arithmetic ratio. This principle led to debate and discussion about whether agricultural production would be able to sustain growing populations [2]. The International Food Policy Research Institute also stated that the demand of food increased by 39 percent between 1995 and 2020 associated with population growth, particularly in Asian countries. Laos has the lowest population in ASEAN and, since 1990, has had a density of only 17.6 person $/ \mathrm{km}^{2}$ [3]. About $1,638,000$ households, or $95 \%$ of the total population, practice swidden farming for subsistence [4]. Swidden farming is presently practiced in the northern uplands of Laos because no other farming choices are available due to the upland conditions [5]. Due to the low population density, swidden farming can be environmentally sustainable and provides enough rice for subsistence livelihoods [6]. It has also been found that diverse sources of food are grown using the swidden farming system [7]. However, in response to the population increase, swidden farming is considered to pose a serious problem in terms of deforestation and environmental degradation, thus leading to land use and land cover changes [8]. Nonetheless, swidden farming continues to be used for subsistence food production in many mountainous regions [9].

Since the 1990s, the government has implemented land use zoning and land use planning based on the 1996 Forest Law. The intention of these directions was to promote 
both forest conservation and the development of a market economy in agriculture [10]. The national policies were implemented to eliminate the swidden farming system by promoting the integration of economic development and rural development, including the production of maize and job's tear in the Xiengkhouang and Xayaboury provinces [11].

Rubber trees (Hevea brasiliensis) constitute a monocropping system. They were also promoted in Luang Namtha province to replaced swidden farming in mountainous regions [12]. The government opened calls for private sectors investment in rubber tree extensions by providing long-term loans or contract farming to swidden farmers. The Chinese private sector and enterprises were also encouraged by China's Opium Replacement Program (ORP) to participate in alternative development in bordering provinces [13]. However, the expanse of rubber tree plantations was not properly controlled, and resulted in the replacement of swidden farming and the conversion of natural forest land to rubber plantations [14]. In 2009, more than 140,000 ha of rubber was planted in Laos, and was estimated to reach 300,000 ha in the 2010s [15]. Luang Namtha province is the biggest planted area. In 2005, the area planted in rubber trees in Luang Namtha was 5213 ha, and increased to 35,000 ha in 2010 , equal to $25 \%$ of the total planted area in the north and $15 \%$ of total planted area in the country $[16,17]$. However, because the population of Lao increased by $1.4 \%$, the highest rate of increase among neighboring countries [18], the continued replacement of swidden rice due to the expansion of rubber plantations may have impacted on the food condition of rural people in the northern part of Laos.

Food security in Laos has long been managed by the Ministry of Agriculture and Forestry [19]. The Agricultural Development Strategy 2025 and Vision for 2030 identified four components of food security, namely, food access, food availability, food safety and nutrition, and food stability. However, the major concerns in this study focus on household food availability and food access. The strategy aims to achieve a level of food availability that meets each household's needs, which was found to equal a rice production of 1.64 ton per hectare or $234 \mathrm{~kg} /$ person/year of paddy. The strategy also aims to provide household food access to those households with an income above the international poverty line, and promotes wild food gathering and vegetable production to increase food source diversity [20]. However, motivating farmers to grow crops for the market alone is an inadequate means for increasing food security in rural areas, because the markets for cash crops are uncertain and cannot generate enough profits for household expenditure [21].

Changing farming systems from food to commercial farming typically increases the expenditure on food [22]. In the Laos context, swidden-based farming provides high food availability, including for rice, crops, and non-timber forest products (NTFPs), from various years of fallow [23]. In contrast, rubber farmers earn their incomes from rubber farming alone, and food security is therefore vulnerable. In 2016, rubber prices fell rapidly from USD 2.3 to 0.6 in 2015 and remained low until 2016. Rubber farmers could not sell their products, although the farmers had contracts with various companies. No action was taken by the government to address the rubber price crisis. As a result, rubber farmers were faced with the problem of food shortages and many returned to swidden farming by clearing natural forests to grow rice [24]. The impact of the rubber tree extension policy to replace swidden farming allowed farmers in communities to split into three types of farming systems. Swidden-based farming is conducted by a small group of farmers who still use the same farming technique. Rubber-based farming is undertaken by a group of farmers who progressed to only grow rubber trees. Swidden-rubber-based farming comprises the majority group of farmers, who decided to maintain rice production and generate income from rubber [24].

Thus, this study provides an comparison of the household food security of these farming systems in a selected area of Laos. This paper uses two dimensions of food security, household food availability and household food accessibility, to compare the household food security levels of different farming types in Luang Namtha province, Lao PDR. 


\section{Materials and Methods}

\subsection{Study Area}

Luang Namtha province has the biggest rubber tree plantation area in Laos. The province consists of five districts: Luang Namtha, Sing, Long, Viengphoukha, and Nalae. Luang Namtha district has the biggest planted area and rubber production area compared to the other districts of Luang Namtha province. Therefore, Luang Namtha district was selected as the focus district for this research (Figure 1).

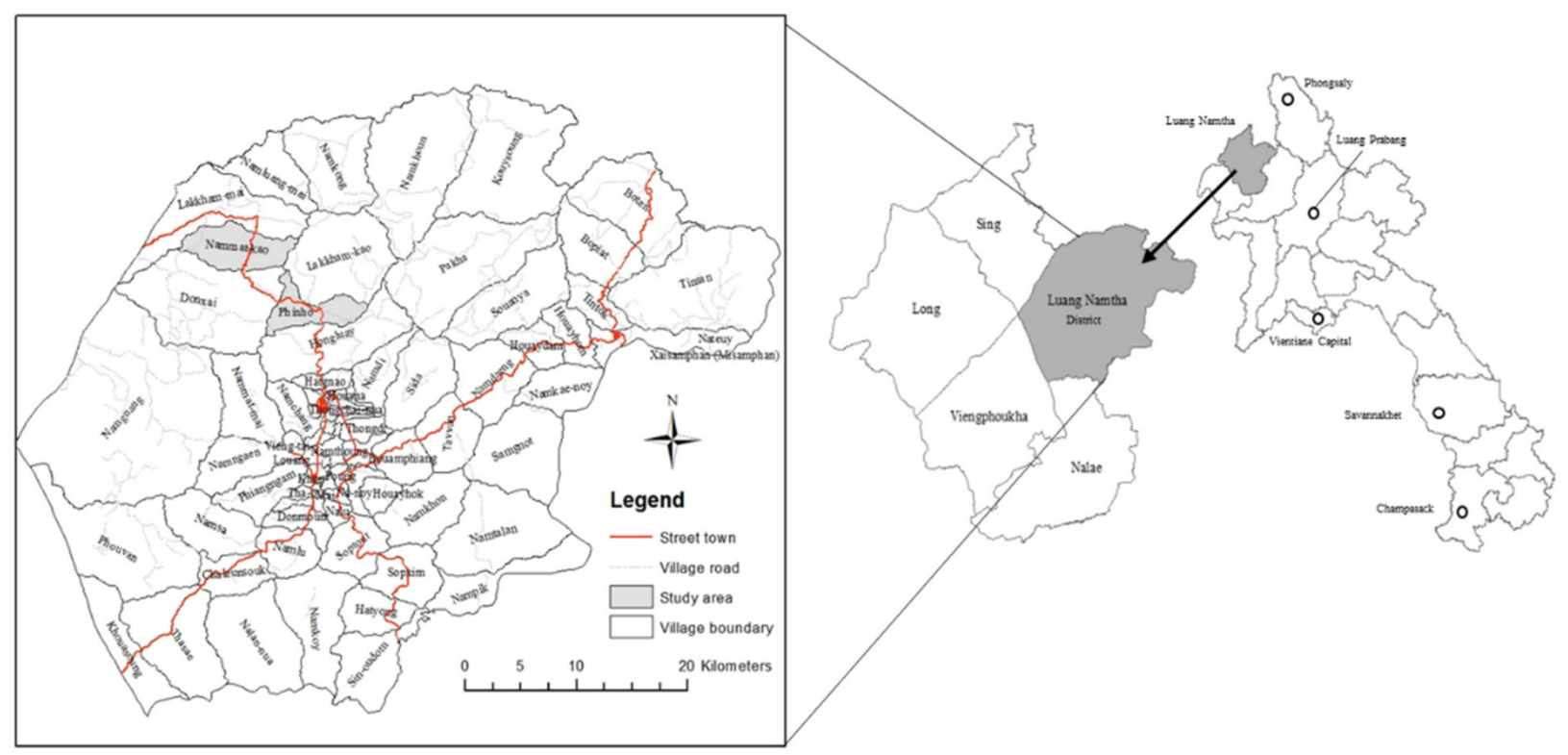

Figure 1. Location of the selected village study sites.

In Luang Namtha district, Phinhor and Nammat Kao villages were purposely selected because some villagers still practice traditional swidden-based farming (SBF), some have shifted to rubber-based farming (RBF), and some villagers practice both swidden- and rubber-based farming (SRBF).

\subsection{Conceptual Framework of the Study}

Traditional swidden farming is a fundamental farming system in the northern part of Laos. The government's policies to replace swidden farming by promoting rubber tree cultivation have had a significant impacts, changing the farming system into three types of farming, namely, swidden-based farming (SBF), rubber-based farming (RBF), and swidden-rubber-based farming (SRBF). These farming types have different strategies to cope with food insecurity. Food security is defined by the World Bank as "access of all people at all times to enough food for an active, healthy life" [25]. Four dimensions of food security (food access, food availability, food utilization, and food stability) are commonly used for the measurement of food security at the national to individual levels [19]. At the household level, food access and food availability are more appropriate for assessing the capacity of a farming strategy to address food insecurity.

Food access refers to "access by individuals to adequate resources for acquiring appropriate foods for a nutritious diet" [19]. At the household level, this paper considers food access to be the ability of a household to obtain food from the wild, markets, or farms. Food availability is defined as "the availability of sufficient quantities of food of appropriate quality, supplied through domestic production or imports" [19]. At the household level, this paper considers food availability to be the availability of food from household production which is sufficient for consumption. 
To measure the level of household food security, the indicators of food access and food availability were set according to the Laotian national policy on food security, as shown in Figure 2.

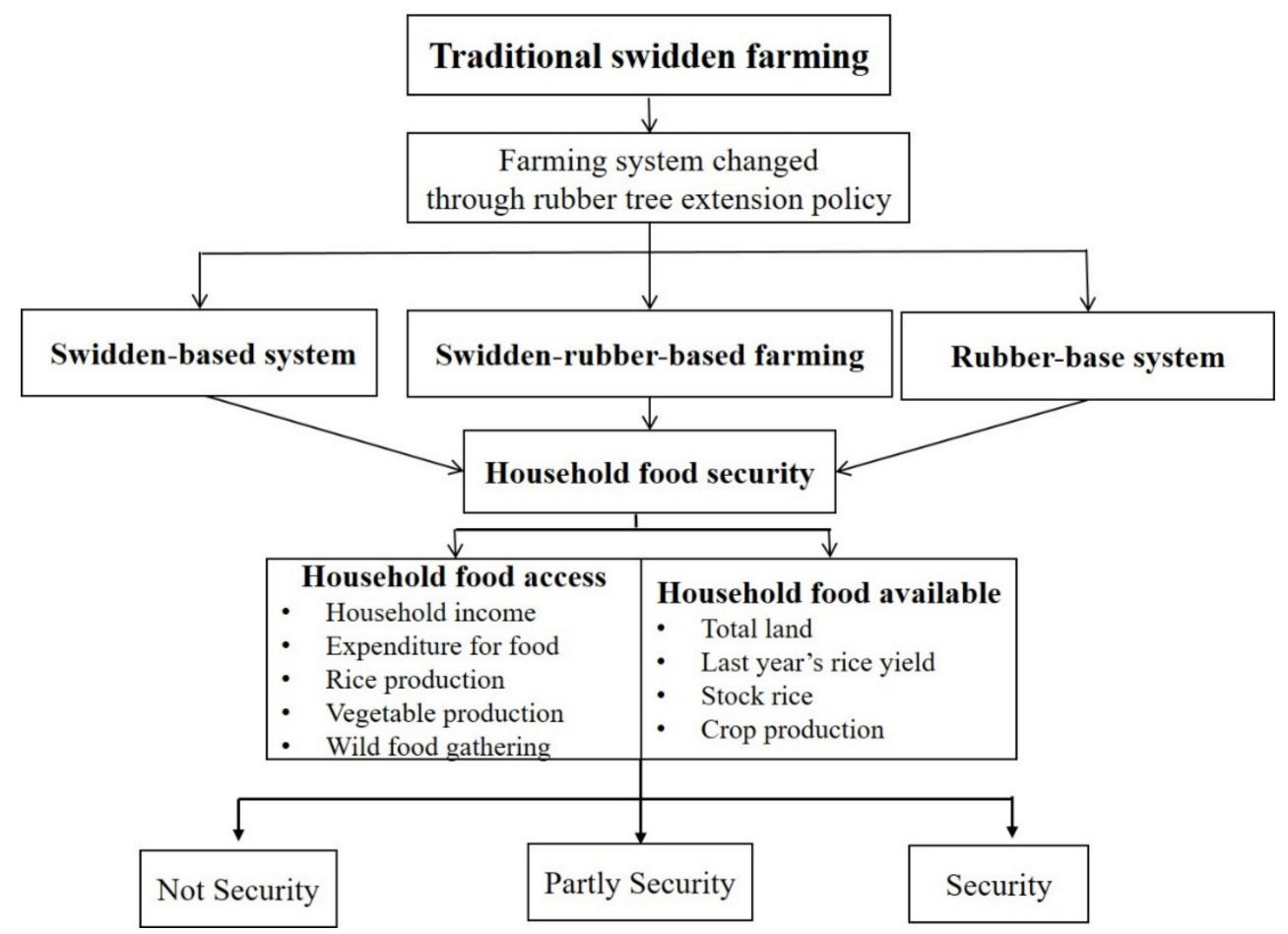

Figure 2. Conceptual framework of the study.

\subsection{Household Sampling Method}

The list of households used in this study included the names of farmers who practice swidden-based farming alone, rubber-based farming alone, and swidden-rubber-based farming from the two villages, which were separated into a single list for simple random sampling (Table 1). The total sampling size was computed using the following formula (1), according to Yamane (1973) [26]:

$$
\mathrm{n}=\frac{\mathrm{N}}{\left(1+\mathrm{Ne}^{2}\right)}
$$

where:

n-Sample size

$\mathrm{N}$-Population size

e-Desired marginal error (a permissible error of five percent was used in this study).

\subsection{Data Collection}

The primary data collection was conducted in May 2017 by in-depth interviews of key informants, focus group discussions, and face-to-face household interviews. The face-to-face interview used a semi-structured method to gather information regarding the household access to land, labor, capital, and markets, and yield, income, and other food security indicators of the selected villages, among the three types of farming systems. 
Table 1. Population size of households for different farming types in the selected villages.

\begin{tabular}{|c|c|c|c|c|c|}
\hline \multirow[b]{2}{*}{ Village } & \multirow[b]{2}{*}{$\begin{array}{c}\text { Total Household } \\
\text { Number }\end{array}$} & \multicolumn{3}{|c|}{ Sampling Household Number } & \multirow[b]{2}{*}{ Total } \\
\hline & & $\begin{array}{c}\text { SBF } \\
(\mathrm{N}=27)\end{array}$ & $\begin{array}{c}\text { RBF } \\
(N=73)\end{array}$ & $\begin{array}{c}\text { SRBF } \\
(N=158)\end{array}$ & \\
\hline Phinhor & 206 & 17 & 60 & 67 & 144 \\
\hline Nammat Kao & 52 & 7 & 1 & 43 & 51 \\
\hline Total & 258 & 24 & 61 & 110 & 195 \\
\hline
\end{tabular}

Discussions were conducted with key informants, including village heads, village elders, and rubber selling groups, who were interviewed to understand some physical, biological, and socio-economic aspects of the villages. Focus group discussions (FGDs) were conducted in each village with purposive selection of representatives of different groups of people, such as those who are wealthy, middle-income, poor, landless, lacking labor, and women. The total number in each group was 15 people. These groups were used to generate qualitative information on land use change, swidden-based practices, and rubber-based practices related to household food security.

\subsection{Measurement Indicators}

This study used two dimensions of food security, namely, household food availability and household food access, to compare the impact on households who changed farming system from food production to rubber tree plantation. The household food availability indicator was measured by independent variables as follows:

\begin{tabular}{|c|c|c|}
\hline Indicator & Score & References \\
\hline $\begin{array}{l}\mathrm{Y} 1=\text { Total land holding (planted + rental } \\
+ \text { fallow + rubber plantation) }\end{array}$ & $\begin{array}{l}<1 \text { ha }=1 \\
1 \text { to } 3 \text { ha }=2 \\
>3 \text { ha }=3\end{array}$ & $\begin{array}{l}\text { Max. land for cultivating rice is limited to one } \\
\text { hectare per labor force in the family; Land for } \\
\text { industrial plantation is limited to three hectares } \\
\text { per labor force in the family [27] }\end{array}$ \\
\hline $\mathrm{Y} 2$ = Last year rice production & $\begin{array}{l}<1.68 \mathrm{Ton} / \mathrm{ha}=1 \\
\geq 1.68 \mathrm{Ton} / \mathrm{ha}=2\end{array}$ & $\begin{array}{l}\text { Average } 280 \mathrm{~kg} \text { of paddy rice/person/year or } 1680 \\
\mathrm{~kg} / \text { household/year [20] }\end{array}$ \\
\hline Y3 = Stock rice (kg of paddy) & $\begin{array}{l}<53 \mathrm{~kg}=1 \\
\geq 53 \mathrm{~kg}=2\end{array}$ & Average $53 \mathrm{~kg} /$ household/month [20] \\
\hline $\mathrm{Y} 4=$ Crops production $(\mathrm{kg})$ & $\begin{array}{l}<52.5 \mathrm{~kg}=1 \\
\geq 52.5 \mathrm{~kg}=2\end{array}$ & $\begin{array}{l}\text { Sweet corn }=2.5 \mathrm{~kg} \text { and vegeThe estimating of } \\
\text { household food } 0 \mathrm{~kg} \text { [20] }\end{array}$ \\
\hline
\end{tabular}

The household food availability indicator was measured by independent variables. These indicators were identified based on Intarapoom [28] as follows:

\begin{tabular}{lll}
\hline Indicator & Score & Reference \\
\hline \multirow{2}{*}{ Y1 = Household income } & $<694$ USD/year $=1$ & 1.9 USD/day or 694 USD/year is the international \\
& $\geq 694$ USD/year $=2$ & poverty line based on the World Bank [29] \\
Y2 = Expenditure on food & $<49 \%$ of total income $=1$ & $49 \%$ is the national average of expenditure for food \\
& $\geq 49 \%$ of total income $=2$ & based on LSB [30] \\
Y3 = Rice production & Non-swidden farmer $=1$ & World Food Programme [31] \\
& swidden farmer $=2$ & \\
Y4 = Vegetable production & Not produce $=1$ & World Food Programme [31] \\
& Produce $=2$ & \\
Y5 = Wild food gathering & Not gathering $=1$ & World Food Programme [31] \\
& Gathering sometime $=2$ & \\
\hline
\end{tabular}

In this study, two pillars of food security (availability and access) were processed by estimating the food security index in a linear form [32] as follows. 


\subsubsection{Household Food Availability (HHFAv)}

The estimating of household food available index is shown as follows:

$$
\mathrm{HHFAv}=\int_{j=1}^{4} b j \mathrm{Yj}=\mathrm{b} 1 \mathrm{Y} 1+\mathrm{b} 2 \mathrm{Y} 2+\mathrm{b} 3 \mathrm{Y} 3+\mathrm{b} 4 \mathrm{Y} 4
$$

This study assumed equal weights for each indicator of HHFAv as follows:

$\mathrm{b}=$ weight $=0.25$ where:

$\mathrm{Y} 1$ - Total land $(<1$ ha $=1 ; 1-3 \mathrm{ha}=2 ;>3 \mathrm{ha}=3)$

Y2-Last year's rice yield (less than $1.68 \mathrm{Ton} / \mathrm{ha}=1$; equal to or higher than 1.68 Ton $/$ ha $=2$ )

Y3-Stock rice (less than $53 \mathrm{~kg}=1$; equal or higher $53 \mathrm{~kg}=2$ )

Y4-Crop production (less than $52.5 \mathrm{~kg}=1$; higher than $52.5 \mathrm{~kg}=2$ ).

Level of analysis:

$$
\text { Thresholds }=\frac{\text { Max }- \text { Min }}{\text { No. level }}=\frac{2.50-1.00}{3}=0.50
$$

Note: maximum score $=2.50$; minimum score $=1.00$

Level 1-Not Available: score between 1.00 to 1.50

Level 2-Partly Available: score between 1.51 to 2.00

Level 3-Available: score between 2.01 to 2.50 .

\subsubsection{Household Food Access (HHFAc)}

The estimating of household food access index is shown as follows:

$$
\mathrm{HHFAc}=\sum_{\mathrm{k}=1}^{4} \mathrm{C}_{\mathrm{k}} \mathrm{Y}_{\mathrm{k}}=\mathrm{C} 1 \mathrm{Y} 1+\mathrm{C} 2 \mathrm{Y} 2+\mathrm{C} 3 \mathrm{Y} 3+\mathrm{C} 4 \mathrm{Y} 4+\mathrm{C} 5 \mathrm{Y} 5
$$

This study assumed equal weights for each indicator of HHFS as follows:

$C=$ weight $=0.25$

where:

Y1-Household income ( $<$ poverty line $=1 ; \geq$ poverty line $=2$ )

Y2-Expenditure for food ( $<49 \%$ of total income $=1 ; \geq 49 \%$ of total income $=2)$

$\mathrm{Y} 3$-Rice production $(\mathrm{No}=1$; Yes $=2)$

$\mathrm{Y} 4-$ Vegetable production $(\mathrm{No}=1 ; \mathrm{Yes}=2)$

Y5-Wild food gathering ( $\mathrm{No}=1$; sometime $=2$; always $=3$ ).

Level of analysis:

$$
\text { Thresholds }=\frac{\text { Max }- \text { Min }}{\text { No.level }}=\frac{2.20-1.00}{3}=0.40
$$

Note: maximum score $=2.20$; minimum score $=1.00$

Level 1-Not Accessible: score between 1.00 to 1.40

Level 2-Partially Accessible: score between 1.41 to 1.81

Level 3-Accessible: score between 1.82 to 2.20.

\subsubsection{Household Food Security (HHFS)}

To identify the level of HHFS, the study compared groups of the HHFAv and HHFAc as follows:

When food is Not Available and Not Accessible $=$ Not Secure

When food is Not Available but Partially Accessible = Not Secure

When food is Not Available but Accessible = Partially Secure

When food is Partially Available and Not Accessible $=$ Not Secure

When food is Partially Available and Partially Accessible = Partially Secure

When food is Partially Available and Accessible = Secure 
When food is Available but Not Accessible = Partially Secure

When food is Available but Partially Accessible = Secure

When food is Available and Accessible = Secure

The HHFS score was also calculated using the formula as follows:

$$
\mathrm{HHFS}=\mathrm{W} 1 * \mathrm{HHFAv}+\mathrm{W} 2 * \text { HHFAc. }
$$

This study assumed equal weights for each indicator of HHFS as follows:

Weight: $\mathrm{W}=0.4$.

\subsection{Data Analysis}

The data received from the key informant group discussions were described as qualitative information. The data attained from the focus group discussions were analyzed as qualitative information on the farming system in the selected villages. For the face-to-face interviews, the data were statically analyzed using descriptive statistics to compare the percentages for RBF, SBF, and SRBF.

The food security scores of HHFAv, HHFAc, and HHFS were calculated using IPM SPSS Statistics for Windows, Version 21.0 [33]. Descriptive statistics (mean and percentage) and one-way ANOVA were used to compare the means of the three farming types, followed by a least significant difference (LSD) post-hoc test when the data had a normal distribution.

\section{Results}

\subsection{Summary of Indicators}

The indicators of different farming types are summarized in Table 2.

\subsection{Village profiles}

Luang Namtha province is located in the northern part of Laos, and shares a border with Myanmar and China. The province underwent a rapid transition from traditional swidden farming to a rubber-based farming system after the 2000s due to its location, near the Chinese border, where there is a high demand for rubber [34]. Of the selected villages, Phinhor village is located about $20 \mathrm{~km}$ from Luang Namtha municipality, and Nammat Kao village is located about $30 \mathrm{~km}$ from the municipality of Luang Namtha province. There was a total of 206 households in Phinhor and 52 households in Nammat Kao.

Three types of farming are practiced in the selected villages, namely, swidden-based farming alone, rubber-based farming alone, and both swidden- and rubber-based farming. A small portion $(12 \%)$ use swidden-based farming alone. About $57 \%$ of the villagers practice both swidden- and rubber-based farming, and about $31 \%$ of villagers completely changed to rubber-based farming [35].

The family size of each type of farming was almost the same. Families undertaking SBF, RBF, or SRBF have between 5 and 6 family members. These are the standard family sizes in Luang Namtha province, and are consistent with the Lao Statistic Bureau (2015) [36]. The percentage of household heads who did not attend school is high and differs according to the farming system: for SBF, it is equal to $42 \%$, whereas for RBF and SRBF, it is $36 \%$ and $33 \%$, respectively. There are five ethnic groups in the selected villages. The majority of the respondents are Hmong, Khmu, and Aka, whereas those who are Lantan and Lao represent only $12 \%$ and $2 \%$ of the population, respectively.

The respondents engaged in rubber-based farming and swidden-rubber-based farming have mainly grown rubber since 2006. About $33 \%$ of the respondents were supported by the government between 2000 and 2003, and only 15\% of respondents started to grow rubber trees in 2004-06 during Chinese private companies' extension programs. The oldest rubber trees were grown by four respondents in rubber-based farming prior to 2000 . 
Table 2. Summary of the indicators.

\begin{tabular}{|c|c|c|c|c|c|c|c|c|}
\hline \multirow{2}{*}{ Description } & \multicolumn{2}{|c|}{ SBF $(n=24)$} & \multicolumn{2}{|c|}{ RBF $(n=61)$} & \multicolumn{2}{|c|}{ SRBF $(n=110)$} & \multicolumn{2}{|c|}{ Total $(n=195)$} \\
\hline & $\mathbf{N}$ & $\%$ & $\mathbf{N}$ & $\%$ & $\mathbf{N}$ & $\%$ & $\mathbf{N}$ & $\%$ \\
\hline Total land holding (ha) & 24 & 100 & 61 & 100 & 110 & 100 & 195 & 100 \\
\hline Less than 1 ha & 10 & 42 & 18 & 30 & 3 & 2.0 & 31 & 16 \\
\hline Between 1-3 ha & 11 & 46 & 24 & 39 & 59 & 54 & 94 & 48 \\
\hline Higher than 3 ha & 3 & 12 & 19 & 31 & 48 & 44 & 70 & 36 \\
\hline Last year rice production & 24 & 100 & 61 & 100 & 110 & 100 & 195 & 100 \\
\hline Lower 1680 kg/year & 21 & 88 & 61 & 100 & 73 & 66 & 155 & 79 \\
\hline $\begin{array}{l}\text { - } \quad \text { Equal or higher than } \\
1680 \mathrm{~kg} / \text { year }\end{array}$ & 3 & 12 & - & - & 37 & 34 & 40 & 21 \\
\hline Stock paddy rice & 24 & 100 & 61 & 100 & 110 & 100 & 195 & 100 \\
\hline Less than $53 \mathrm{~kg}$ & 17 & 71 & 60 & 98 & 64 & 58 & 141 & 72 \\
\hline Equal or higher than $53 \mathrm{~kg}$ & 7 & 29 & 1 & 2 & 46 & 42 & 54 & 28 \\
\hline Crops production & 24 & 100 & 61 & 100 & 110 & 100 & 195 & 100 \\
\hline Lower than $52.5 \mathrm{~kg}$ & 13 & 54 & 60 & 98 & 67 & 61 & 140 & 72 \\
\hline Equal or higher than $52.5 \mathrm{~kg}$ & 11 & 46 & 1 & 2 & 43 & 39 & 55 & 28 \\
\hline Household income status & 24 & 100 & 61 & 100 & 110 & 100 & 195 & 100 \\
\hline $\begin{array}{l}\text { - Higher and equal than } \\
\text { poverty line }\end{array}$ & 2 & 8 & 8 & 13 & 17 & 15 & 27 & 14 \\
\hline Lower than poverty line & 22 & 92 & 53 & 87 & 93 & 85 & 168 & 86 \\
\hline Expenditurefor Food & 24 & 100 & 61 & 100 & 110 & 100 & 195 & 100 \\
\hline $\begin{array}{l}\text { - } \quad \text { Payment of food less than } \\
49 \% \text { of total income }\end{array}$ & 6 & 25 & 25 & 41 & 36 & 33 & 67 & 34 \\
\hline $\begin{array}{l}\text { Payment of food more than } \\
49 \% \text { of total income }\end{array}$ & 18 & 75 & 36 & 59 & 74 & 67 & 128 & 66 \\
\hline Rice production & 24 & 100 & 61 & 100 & 110 & 100 & 195 & 100 \\
\hline Not access & 0 & 0 & 60 & 98 & 0 & 0 & 60 & 31 \\
\hline Access & 24 & 100 & 1 & 2 & 110 & 100 & 135 & 69 \\
\hline Vegetable production & 24 & 100 & 61 & 100 & 110 & 100 & 195 & 100 \\
\hline Not access & 9 & 37 & 1 & 2 & 43 & 39 & 53 & 27 \\
\hline Access & 15 & 63 & 60 & 98 & 67 & 61 & 142 & 73 \\
\hline Wild food gathering & 24 & 100 & 61 & 100 & 110 & 100 & 195 & 100 \\
\hline Not Access & 16 & 66 & 32 & 53 & 56 & 51 & 104 & 53 \\
\hline Partly access & 5 & 21 & 21 & 34 & 22 & 20 & 48 & 25 \\
\hline Always access & 3 & 13 & 8 & 13 & 32 & 29 & 43 & 22 \\
\hline
\end{tabular}




\subsection{Household Food Availability (HHFAv)}

In general, the experience of households regarding rice shortages depends on the farming type. The RBF group had the largest percentage of households who experienced a rice shortage (98\%), whereas the greatest percentage of rice-sufficient households $(78 \%)$ was found in the SRBF group (Table 3). Therefore, the RBF members must buy paddy rice from the market for household consumption.

Table 3. Household rice shortages for different farming types in the selected villages.

\begin{tabular}{ccccc}
\hline \multirow{2}{*}{ Type of Farming } & \multicolumn{2}{c}{ Sufficient Rice } & \multicolumn{2}{c}{ Shortage Rice } \\
\cline { 2 - 5 } & No. & No. & 7 & 29 \\
\hline Swidden-based farming $(n=24)$ & 17 & 71 & 60 & 98 \\
Rubber-based farming $(n=61)$ & 1 & 2 & 24 & 22 \\
Swidden-rubber-based farming $(n=110)$ & 86 & 78 & 51 & 47 \\
\hline Grand total $(n=195)$ & 104 & 53 & & \\
\hline
\end{tabular}

Note: Only one household in rubber-based farming has sufficient rice from a paddy rice field in the lowland of another village.

The study compared the household food availability (HHFAv) among the different farming types. HHFAv is either not available (score 1.00 to 1.50), partially available (score 1.51 to 2.00), or available (score 2.01 to 2.50). This study found that the maximum food availability level (34\%) was obtained in the SRBF group, whereas the lowest food availability level was obtained in the RBF (Table 4).

Table 4. Household food availability level of different farming types in the selected villages.

\begin{tabular}{ccccccc}
\hline \multirow{2}{*}{ Type of HH Farming } & \multicolumn{2}{c}{ Not Available } & \multicolumn{2}{c}{ Partly Available } & \multicolumn{2}{c}{ Available } \\
\cline { 2 - 7 } & No. & $\%$ & No. & \% & No. & 8 \\
Swidden-based farming $(n=24)$ & 14 & 58 & 8 & 33 & 2 & 0 \\
Rubber-based farming $(n=61)$ & 40 & 66 & 21 & 34 & 37 & 34 \\
Swidden-rubber-based farming $(n=110)$ & 25 & 23 & 48 & 44 & 39 & 39 \\
\hline Grand total $(n=195)$ & 79 & 41 & 77 & 39 \\
\hline
\end{tabular}

\subsection{Household Food Access (HHFAc)}

In the comparison of the household food access (HHFAc) among the different farming types, HHFAc was sorted into three levels of food access: not accessible (score 1.00-1.40), partially accessible (score 1.41-1.81), and accessible (score 1.82-2.20). The study revealed that $23 \%$ of the households in SRBF had access to food, whereas the RBF group had no households who reached the highest level of food access (Table 5).

Table 5. Household food access level of the different farming types in the selected villages.

\begin{tabular}{ccccccc}
\hline \multirow{2}{*}{ Type of HH Farming } & \multicolumn{2}{c}{ Not Access } & \multicolumn{2}{c}{ Partly Access } & \multicolumn{2}{c}{ Access } \\
\cline { 2 - 7 } & No. & \% & No. & \% & No. & \% \\
\hline Swidden-based farming $(n=24)$ & 10 & 42 & 11 & 46 & 3 & 13 \\
Rubber-based farming $(n=61)$ & 47 & 77 & 14 & 23 & 0 & 0 \\
Swidden-rubber-based farming $(n=110)$ & 23 & 21 & 62 & 56 & 25 & 23 \\
\hline Grand total $(n=195)$ & 80 & 41 & 87 & 45 & 28 \\
\hline
\end{tabular}

\subsection{Household Food Security (HHFS)}

The study found that about $57 \%$ of the households in the selected villages could be identified as not secure (Table 6). These results are consistent with other findings in South-East Asian countries following the replacement of rice production with natural rubber plantations, which can threaten the food security of local communities in poor countries. However, although some households continued to practice swidden-based farm- 
ing, rice production under this farming type remained low because fallow periods were shortened to improve the soil fertility and in response to uncertain rainfall. In the present study, most households demonstrated rice sufficiency for 8.9 months ( $\mathrm{min}=5$ months; $\max =10.5$ months). Previous research in Xiengkhouang province by Keoboualapha et al. (2013) [37] found that about 58\% of farmers experienced a rice shortage for 3-4 months a year under slash-and-burn cultivation (swidden-based farming). According to the interviews conducted in the present study, farmers in the RBF group used all of their money to buy rice for household consumption, particularly outside of the rubber tapping season (in the dry season from November to March), whereas farmers in the SBF and SRBF groups consumed their own rice to reduce the expenditure for food.

Table 6. Level of household food security among different farming types in the selected villages.

\begin{tabular}{|c|c|c|c|c|c|c|}
\hline \multirow{2}{*}{ Type of HH Farming } & \multicolumn{2}{|c|}{ Not Security } & \multicolumn{2}{|c|}{ Partly Security } & \multicolumn{2}{|c|}{ Security } \\
\hline & No. & $\%$ & No. & $\%$ & No. & $\%$ \\
\hline Swidden-based farming $(n=24)$ & 16 & 67 & 3 & 12 & 5 & 21 \\
\hline Rubber-based farming $(n=61)$ & 59 & 97 & 2 & 3 & 0 & 0 \\
\hline Swidden-rubber-based farming $(n=110)$ & 37 & 34 & 47 & 44 & 26 & 24 \\
\hline Grand total $(n=195)$ & 112 & 57 & 52 & 27 & 31 & 16 \\
\hline
\end{tabular}

The comparison of the food security among the different types of farming showed that households in rubber-based farming were not able to obtain the food security level, whereas about $24 \%$ of the total households in swidden-rubber-based farming obtained the food security level, and only $21 \%$ of the households in swidden-based farming obtained the food security level (Table 6).

\subsection{Food Security Indicators Affecting the Different Farming Types}

In the comparison of the household food security of the different farming types, the present study illustrated that the households of the RBF group showed significantly lower $(p<0.01)$ household food access than the SBF and SRBF groups (Table 7). This is because the rubber-based farming system is a monocropping system. Although the RBF farmers received better income from selling rubber, their average income was not sufficient to buy food. Thus, gathering wild food such as bamboo or vegetables, or fishing, are alternative means of reducing household expenditure. The households of RBF and SBF have the same levels of household food availability and household food security, but were both significantly lower than those of SRBF (Table 7). In summary, the present study found that the households of the SRBF group had the highest food security, followed by the SBF group and, finally, the RBF group. This is due to the limitation of land for both households of SBF and RBF, which was the main indicator on this study.

Table 7. Mean of food security indicators for the different farming types in the selected villages.

\begin{tabular}{cccccccc}
\hline \multirow{2}{*}{ Indicator } & \multicolumn{2}{c}{ SBF $(\boldsymbol{n}=\mathbf{2 4})$} & \multicolumn{2}{c}{ RBF $(\boldsymbol{n}=\mathbf{6 1})$} & \multicolumn{2}{c}{ SRBF $(\boldsymbol{n}=\mathbf{1 1 0})$} & \multirow{2}{*}{ F-Ratio } \\
\cline { 2 - 6 } & Mean & SD & Mean & SD & Mean & SD & \\
\hline HHFAc & $1.75 \mathrm{a}$ & 0.68 & $1.13 \mathrm{~b}$ & 0.34 & $1.85 \mathrm{a}$ & 0.68 & $30.1^{* *}$ \\
HHFAv & $1.50 \mathrm{~b}$ & 0.66 & $1.34 \mathrm{~b}$ & 0.48 & $2.11 \mathrm{a}$ & 0.75 & $28.8^{* *}$ \\
HHFS & $1.22 \mathrm{~b}$ & 0.19 & $1.16 \mathrm{~b}$ & 0.17 & $1.44 \mathrm{a}$ & 0.18 & $57.6^{* *}$ \\
\hline
\end{tabular}

Note: $\mathrm{SD}=$ standard deviation; ${ }^{* *}=$ significant difference at $p \leq 0.01$. Means in the same row followed by different letters are significantly different at $p \leq 0.05$ by LSD.

\section{Discussion}

This study identified three types of farming in the selected villages, namely, the swidden-based farming system (SBF), rubber-based farming system (RBF), and swiddenrubber-based farming system (SRBF). The study highlighted two components of food 
security of the Agricultural Development Strategy 2025 and Vision for 2030, namely, food access and food availability, which are discussed as follows.

\subsection{Household Food Availability}

To increase household food availability in Laos, the government promoted household production of food, and particularly the staple crop of rice [20]. The indicators used in this study to measure food availability included total land area, last year's rice production, stock of rice per month, and crop production. The results of this study indicated that the household practices of SRBF achieved the maximum food availability level (34\%), whereas the lowest food availability level was achieved by RBF (Table 3). The reasons for these results are as follows:

(1) Land was an incentive for farmers to spend time, energy, and money to increase the productivity and sustainability of their lands [38]. In the selected villages, about $48 \%$ of the households owned 1-3 ha of planted area, 36\% owned more than 3 ha, and $16 \%$ owned less than 1 ha of land. The farmers in SRBF held more land than farmers in the other types of farming. On average, SRB farmers had an area of land for farming of about 0.8 ha, RBF farmers had 2.23 ha, and SRBF farmers had an average land area of 3.06 ha. The origins of the land in the selected villages are complicated, but most of the land is under customary tenure rights. A study in Luang Namtha province by Thongmanivong et al. (2009) [39] noted that farmers transformed swidden fallow land into rubber plantations, but only pioneer farmers or farmers with existing assets (cattle or funds) were able to quickly transform the land, and thus reserve a greater area. In this study, RBF and SRBF farmers are also pioneer farmers, or have existing assets that can be reserved and are able to convert swidden land into rubber.

(2) Household rice production refers to the Laos agricultural strategy, which states that household food production should not be less than $1680 \mathrm{~kg} /$ year, with a paddy rice stock per household of $53 \mathrm{~kg} /$ month [20]. However, this study found that each type of farm experienced low rice productivity (Table 3). About $79 \%$ of households had rice production lower than $1680 \mathrm{~kg}$ per year, and $72 \%$ of households had a rice stock of less than $53 \mathrm{~kg}$ per month (Table 4). When the farmers transformed swidden-based farming into rubber-based farming alone, rice shortages were a major problem. In a case study in Hat Nyao village in Luang Namtha province, Alton (2005) [40] noted that most of the farmers (SRBF) experienced rice deficiency. The farmers temporarily stopped rubber activities to work on upland swidden rice to reduce the risk of rice insufficiency. This study also found that the tapping season for rubber overlaps with the swidden farming season (April to November). SRBF farmers prioritize the activities of swidden farming or spend more time at night in the rubber plantation, whereas RBF farmers have to increase their tapping of rubber to have sufficient money to buy rice and save funds for the non-tapping season (December to March).

(3) Vegetable production also declined with the transition to RBF, because the Laos agricultural strategy also determined that household vegetable production should not be below $52.5 \mathrm{~kg} /$ year [20]. SBF and SRBF farmers continued to grow vegetables, and this practice was integrated with rice during the rainy season. Roder (2001) [7] reported that several varieties of vegetables are grown in the same plot as rice, including cucumber, pumpkin, taro, chili, sweet potato, long bean, eggplant, yam bean, and ginger. Pathumphone et al. (2016) [23] also stated that chili, sweet corn, and pumpkin are cultivated with rice in SBF and SRBF groups. However, in addition to food production, gathering wild vegetables from nearby forests, such as bamboo shoots, mushrooms, and galangal, for household consumption also helps to increase household food availability, in terms of both plant and animal products [41]. However, for RBF farmers fully engaged in rubber plantation, food availability also declined. 


\subsection{Household Food Access (HHFAc)}

Household food access indicates the ability of household income to buy sufficient rice and food for household consumption. The indicators used in measuring household food access are household income, expenditure for food, household rice production (optional), vegetable production (optional), and wild food gathered (optional).

The level of income used to indicate a food access level is also associated with the poverty line. Wight (2014) [42] reported that households with an income lower than the poverty line were more vulnerable in terms of food security. The World Bank (2015) [29] indicated that the international poverty line is an income of less than $1.9 \mathrm{USD} /$ day. The results from the selected villages show that about $86 \%$ of households have incomes lower than the poverty line (Table 2). This is mainly attributed to the lower prices of latex (rubber is the main source of income) in 2016, which were only $0.48-0.6 \mathrm{USD} / \mathrm{kg}$. An additional problem during this time was that many rubber investors were not able to buy the latex from farmers even though rubber was produced under contract farming. Only one rubber company continued to buy rubber latex from farmers, at low prices. Some farmers had to clear more land to grow upland rice under swidden-based farming for their own consumption. RBF farmers were particularly affected by this crisis in some years. In contrast, Nhoybouakong et al. (2009) [43] reported the high income of rubber farmers in 2009 , who received an average yearly income of USD 1604. This income was sufficient to buy food. This illustrates that the uncertain rubber situation in Laos also affects long-term food security.

Household expenditure is also related to the income level. The Lao Statistic Bureau [30] indicated that a high share of expenditure for food, of more than $49 \%$ of the total household income, would affect a household's savings and other expenditures. This study found that $66 \%$ of the households in the selected villages spent more than $49 \%$ of their total income on food. The household incomes for swidden-based farming were particularly low, meaning that the percentage of their income spent on food was greater. Additionally, $75 \%$ of the households in swidden-based farming spent more than $49 \%$ of their total income on food, particularly to buy protein sources, such as pork, chicken, and fish, which have higher prices than vegetables.

\subsection{Household Food Security (HHFS)}

Government policies for promoting commercial agriculture and food production to reduce poverty and increase food security in the rural areas of Laos, in response to the Sustainable Development Goals (SDG), are discussed in this paper [44]. The Agricultural Development Strategy 2025 and Vision for 2030 also identified food access and food availability as measures of food security in rural areas [20]. This study indicates the different indicators for the measurement of food availability and food access. The farmers in the SBF and SRBF groups have greater potential for food access, and RBF and SRBF farmers received a high score for food access. However, the results of the combination score of HHFAv and HHFAc indicated that there is a high percentage of farmers in the SRBF group, and RBF farmers have no food security (Table 7). This result indicates that growing rubber trees alone can increase the income but not the level of food security, due to a lack of policies to compensate farmers during periods of weak rubber prices. Similar to the findings in this study, Phasouysaingam (2020) [45] noted that the causes of food insecurity in the rural northern part of Laos are: (1) declining productivity in swiddenbased upland farming systems; (2) declining productivity of non-timber forest resources; and (3) the failure of alternative income sources to transform the rural economy. This confirms that swidden farming alone and rubber plantations alone incur a greater risk in terms of food insecurity.

In the transition from subsistence to commercial agriculture in rural areas, food production, food gathering from the wild, and income should all be maintained. A similar study by Intarapoom (2019) [46] reported the same trend, and found that households who shifted from 100 percent of the planting area consisting of rice to 100 percent of the planting 
area consisting of sugarcane achieved significantly lower HHFAv and HHFS values than those households who planted sugarcane and rice in proportions of 75:25, 50:50, or 25:75. Another case of changing rice to cash crops in Uganda was reported by Ntakyo and van den Berg (2019) [47], which indicated that growing crops for the market cannot reduce food insecurity. It is important to promote both food production and cash crop production to help farmers obtain food security.

\section{Conclusions}

This study aimed to compare household food security in communities that implemented different changes in their farming systems, namely, swidden-based farming alone $(\mathrm{SBF})$, rubber-based farming alone (RBF), and both swidden- and rubber-based farming (SRBF) in Luang Namtha province, Lao PDR. Two dimensions of food security, household food availability and household food access, were used to investigate the household food security level associated with the three farming types. The primary data were gathered from focus group discussions, in-depth interviews with key informant groups, and face-to-face household interviews, with a total of 195 respondents.

The key findings of this study showed that the impacts of changing from swiddenbased farming to rubber-based farming are a high vulnerability and loss in food security. Rubber-based farming alone cannot obtain high values in both the HHFAv and HHFAc indicators, but swidden-based farming alone also left farmers vulnerable in terms of food security. Only $8 \%$ of SBF farmers obtained high HHFAv values, and $13 \%$ obtained high HHFAc values. The households in the SRBF group exhibited higher dimensions of food security compared to the households in either SBF or RBF alone. However, only $28 \%$ of the households surveyed had a rice stock greater than $53 \mathrm{~kg}$ per month, indicating that most of the households in the selected villages are still at risk in terms of rice shortages. Only $18 \%$ of the total households in the selected villages reached the food security threshold. In addition, most of the households (86\%) still earned an income that is lower than the poverty line, and $66 \%$ of the total households in the selected villages spent more than $49 \%$ of their total income on food.

Although the changing of the farming system from swidden-based farming alone to rubber-based farming alone resulted in the lowest food security level, the results for households that did not change from swidden-based farming were also not significantly different from those that did not change from rubber-based farming. The households in swidden-rubber-based farming constitute a major group in the selected villages and obtained the highest food security, but forest governance has become a new issue in the selected villages. The farmers have cleared new forest for growing swidden rice to secure food, which is the opposite outcome to that sought by the forest governance policy. The forest governance policy aims to introduce rubber trees to replace swidden-based farming. This study recommends two solutions for the further development and promotion of household food security: (1) rubber prices should be secured by opening the competitive market in Laos and promoting community rubber processing to improve the quality of the products, and (2) forest and land use allocation should be implemented for swidden-based farming as a collective tenure that could be used by all households within a community for seasonal swidden-based farming.

Author Contributions: A.P. (Avakat Phasouysaingam), and A.P. (Anan Polthanee) worked on the concepts and methodologies for this paper. A.P. (Avakat Phasouysaingam) wrote the paper with contributions of A.P. (Anan Polthanee) and A.P. (Arunee Promkhambut). S.A. analyzed the data with contributions from A.P. (Avakat Phasouysaingam). A.P. (Anan Polthanee) reviewed the paper. All authors have read and agreed to the published version of the manuscript.

Funding: This research was funded by the Khon Kaen University and the Jeunes Equipes Associées à l'IRD program under the JEAI project.

Institutional Review Board Statement: Not applicable. 
Informed Consent Statement: Informed consent was obtained from village chiefs of each village and agreed from all respondents in this study.

Data Availability Statement: Data from this study will be made available from the corresponding author upon request.

Acknowledgments: The authors also would like to thank the anonymous reviewers for their comments that contributed to improving the quality of this paper.

Conflicts of Interest: The authors declare no conflict of interest.

\section{References}

1. Vermeulen, S.J.; Aggarwal, P.K.; Ainslie, A.; Angelone, C.; Campbell, B.M.; Challinor, A.J.; Hansen, J.W.; Ingram, J.; Jarvis, A.; Kristjanson, P. Options for support to agriculture and food security under climate change. Environ. Sci. Policy 2012, 15, 136-144. [CrossRef]

2. Mellos, K. Neo-Malthusian Theory. In Perspectives on Ecology: A Critical Essay; Palgrave Macmillan: London, UK, $1988 ;$ pp. 15-42. [CrossRef]

3. Roder, W. Slash-and-burn rice systems in transition: Challenges for agricultural development in the hills of Northern Laos. Mt. Res. Dev. 1997, 17, 1-10. [CrossRef]

4. Bass, S.; Morrison, E. Shifting Cultivation in Thailand, Laos and Vietnam: Regional Overview and Policy Recommendations; IIED: London, UK, 1994.

5. Yokoyama, S. Forest, ethnicity and settlement in the mountainous area of northern Laos. Jpn. J. South Asian Stud. 2004, 42, 132-156.

6. Kenney-Lazar, M. Shifting Cultivation in Laos: Transitions in Policy and Perspective; Sector Working Group-Agriculture and Rural Development (SWG-ARD): Vientiane, Laos, 2012.

7. Roder, W. Slash-and-Burn Rice Systems in the Hills of Northern Lao PDR: Description, Challenges, and Opportunities; International Rice Research Institute: Los Baños, Philippines, 2001.

8. Souvanthong, P. Shifting Cultivation in Lao PDR: An Overview Of Land Use And Policy Initiatives; IIED: London, UK, 1995.

9. Do, D.S. Shifting Cultivation in Vietnam: Its Social, Economic and Environmental Values Relative to Alternative Land Use; IIED: London, UK, 1994.

10. Takai, Y.; Sibounheuang, T. Conflict between water buffalo and market-oriented agriculture: A case study from Northern Laos. Jpn. J. South Asian Stud. 2010, 47, 451-477.

11. Lestrelin, G.; Castella, J.-C. Opportunities and challenges for the adoption of conservation agriculture in maize production areas of Laos. In Proceedings of Resilient food systems for a changing world. In Proceedings of the 5th World Congress on Conservation Agriculture, WCCA/FSD, Brisbane, Australia, 26-29 September 2010; pp. 42-44.

12. Manivong, V. The Economic Potential for Smallholder Rubber Production in Northern Laos; University of Queensland: Brisbane, Australia, 2007.

13. Lu, J. Tapping into the Rubber Market: Opium Replacement and the Role of Rubber In Developing Laos; BRICS Initiatives for Critical Agrarian Studies (BICAS): Rotterdam, The Netherlands, 2015.

14. Yasmi, Y.; Durst, P.; Haq, R.U.; Broadhead, J. Forest Change in the Greater Mekong Subregion (gms) an Overview of Negative and Positive Drivers; The Food and Agriculture Organization of the United Nations (FAO): Bangkok, Thailand, 2017.

15. Fox, J.; Castella, J.-C. Expansion of rubber (Hevea brasiliensis) in Mainland Southeast Asia: What are the prospects for smallholders? J. Peasant. Stud. 2013, 40, 155-170. [CrossRef]

16. Shi, W. Rubber boom in Luang Namtha. A Transnational Perspective; GTZ RDMA: Vientiane, Laos, 2008.

17. Nolintha, V. Triangle Area Development: Prospects and Challenges for Lao PDR. In Five Triangle Areas in The Greater Mekong Subregion; Ishida, M., Ed.; IDE-JETRO: Bangkok, Thailand, 2012.

18. Ministry of Agriculture and Forestry. The Lao Census of Agriculture (LCA) of 2010/11: Analysis of Selected Themes; Department of Planning and Cooperation, Ministry of Agriculture and Forestry: Vientiane, Laos, 2014.

19. Armstrong, J. Food Security Policy in Lao PDR: An Analysis of Policy Narrativesin Use; University of London: London, UK, 2018.

20. Ministry of Agriculture and Forestry. Agriculture Development Strategy 2025 and Vision To 2030; Ministry of Agriculture and Forestry: Vientiane, Laos, 2015.

21. Thanichanon, P.; Schmidt-Vogt, D.; Epprecht, M.; Heinimann, A.; Wiesmann, U. Balancing cash and food: The impacts of agrarian change on rural land use and wellbeing in Northern Laos. PLoS ONE 2018, 13, e0209166. [CrossRef] [PubMed]

22. Pathumphone, S.; Sanitchon, J.; Polthanee, A.; Promkhambut, A. Food diversity of three ethnic groups: A case study from Xieng Khuang province, Northern Lao PDR. Asia Pac. J. Sci. Technol. 2016, 21, 12-25.

23. Phasouysaingam, A. Impact of Changing Swidden-Based Farming to Rubber Based Farming on Food Security and Socio-Economic Performance of Farmers in Luangnamtha Province, Laos PDR. Ph.D. Thesis, Khon Kaen University, Khon Kaen, Thailand, 2019.

24. Haen, H.; Huddleston, B.; Thomas, H.; Sharma, R. Trade Reforms and Food Security: Conceptualizing the Linkages; Food \& Agriculture Organization: Rome, Italy, 2005.

25. Thomas, H. Trade Reforms and Food Security: Conceptualizing the Linkages; Food Agriculture Organization of the United Nations: Rome, Italy, 2003. 
26. Yamane, T. Statistics: An Introductory Analysis, 2nd ed.; Harper and Row: New York, NY, USA, 1973.

27. National Assembly Standing Committee. Land Law. No. 04/NA; National Assembly: Vientiane, Laos, 2003.

28. Intarapoom, I. The Impacts of Expandable Area on Food Security of Sugarcane Farmers in Khon Kaen Province. Ph.D. Thesis, Mahasalakham University, Talat, Thailand, 2017.

29. World Bank. Global Poverty Line Update. Available online: http://www.worldbank.org/en/topic/poverty/brief/globalpoverty-line-faq (accessed on 30 September 2015).

30. LSB. Food Insecurity Assessment Based on Food Consumption Statistics Derived from the 2002/03 Lao PDR Expenditure and Consumption Survey; National Statistical Centre: Vientiane, Laos, 2007.

31. World Food Programme. Lao PDR: Comprehensive Food Security and Vulnerability Analysis (CFSVA); World Food Programme, Vulnerability Analysis and Mapping Branch (ODAV): Vientiane, Laos, 2008.

32. Conte, A. Thematic Guidelines Household Food Security Profiles; World Food Programme: Rome, Italy, 2005.

33. Almquist, Y.B.; Ashir, S.; Brännström, L. A Guide to Quantitative Methods, Version 1.0.3; Centre for Health Equity Studies: Stockholm, Sweden, 2016.

34. Liu, X.; Jiang, L.; Feng, Z.; Li, P. Rubber plantation expansion related land use change along the Laos-China border region. Sustainability 2016, 8, 1011. [CrossRef]

35. Phasouysaingam, A.; Polthanee, A.; Promkhambut, A.; Aditto, S. Impact of changing of swidden-based farming to rubber-based farming on socio-economic performance in Luang Namtha province, Lao PDR. KKU Int. J. Humanit. Soc. Sci. 2020, 10, $29-56$.

36. Lao Statistic Bureau. The 4th Population and Housing Census (PHC) 2015: Results of Population and Housing Census 2015; National Statistical Centre: Vientiane, Laos, 2015.

37. Keoboualapha, B.; Suchint, S.; Jintrawet, A.; Onpraphai, T.; Polthanee, A. Farmers' perceptions of imperata cylindrica Infestation in a slash-and-burn cultivation area of Northern Lao PDR. Southeast Asian Stud. 2013, 2, 583-598.

38. Kenney-Lazar, M. Linking food and land tenure security in the Lao PDR. Lao PDR: Land Information Working Group, Global Association for People and the Environment (GAPE), and Village Focus International (VFI). 2015. Available online: https: / / data.opendevelopmentmekong.net/en/dataset/2016-6 (accessed on 17 June 2019).

39. Thongmanivong, S.; Fujita, Y.; Phanvilay, K.; Vongvisouk, T. Agrarian Land Use Transformation in Northern Laos. Jpn. J. Southeast Asian Stud. 2009, 47, 330-347.

40. Alton, C.; Bluhm, D.; Sananikone, S. Para rubber study. In Lao-German Program. Rural Development in Mountainous Areas of Northern Lao PDR; GTZ technical reports; GTZ: Vientiane, Laos, 2005.

41. NAFRI. Improving Livelihoods in the Upland of the Lao PDR, Volume 2: Options and Opportunities; National Agriculture and Forestry Research Institute (NAFRI): Vientiane, Laos, 2005.

42. Wight, V.; Kaushal, N.; Waldfogel, J.; Garfinkel, I. Understanding the link between poverty and food insecurity among children: Does the definition of poverty matter? J. Child. Poverty 2014, 20, 1-20. [CrossRef] [PubMed]

43. Nhoybouakong, M.; Malivarn, S.; Souphonphacdy, D.; Rajvong, A.; Baylatry, M.; Voravong, S.; Khamphanh, S. Rubber: Costs or Benefits to the Lao PDR; The Sustainable Mekong Research Network: Bangkok, Thailand, 2009.

44. Bouapao, L.; Insouvanh, C.; Pholsena, M.; Armstrong, J.; Staab, M. Strategic Review of Food and Nutrition Security in Lao People's Democratic Republic; World Food Programme: Vientiane, Laos, 2016.

45. Phasouysaingam, A. Rubber Plantation and Risk Management in Northern of Laos PDR. Bur. Acad. Serv. KKU J. 2020, $28,30-40$.

46. Intarapoom, I.; Srisompun, O.; Sinsiri, N. Impacts of sugarcane farmland expansion towards food security among sugarcanefarming households in Khon Kaen Province, Thailand. Adv. J. Soc. Sci. 2019, 4, 11-17. [CrossRef]

47. Ntakyo, P.R.; van den Berg, M. Effect of market production on rural household food consumption: Evidence from Uganda. Food Sec. 2019, 11, 1051-1070. [CrossRef] 